\title{
A NEW GENE FOR MALE STERILITY IN PIGEONPEA (CAJANUS CAJAN (L). MILLSP.)
}

\author{
K. B. SAXENA*, E. S. WALLIS AND D. E. BYTH \\ Department of Agriculture, University of Queensland St. Lucia - 4067, Brisbane, \\ Australia
}

Received: $1 . i i i .83$

\section{SUMMARY}

\begin{abstract}
Several forms of female fertile and male sterile mutants in pigeonpea (Cajanus cajan (L). Millsp.) have been reported. A translucent anther type of male sterile characterised by non-separation of tetrads that is associated with a persistent tapetum is conditioned by a single recessive gene, $\mathrm{ms}_{1}$ (Reddy et al., 1977; Reddy et al., 1978). By contrast, a male sterile plant identified in breeding line B15B by Wallis et al. (1981) has shrivelled, arrowhead-shaped, non-dehiscent, brown-coloured anthers, and the pollen mother cells degenerate at the early tetrad stage (Dundas et al., 1981). This paper reports studies to determine the inheritance of the $\mathrm{B} 15 \mathrm{~B}$ male sterile character and its allelic relationship to the translucent anther type.
\end{abstract}

Male sterile plants of B15B were crossed with cultivars 3D8103, QPL-1, and Royes. The $F_{1}$ and $F_{2}$ generations and test cross progenies of fertile $F_{1}$ plants crossed to male sterile $B 15 B$ were classified for male fertility. Segregation for fertility was also studied using self-pollinated progenies of random plants from $F_{5}$ lines of male sterile $B 15 B \times Q P L-1$. The allelic relationship between the $\mathrm{B} 15 \mathrm{~B}$ and translucent anther types of male steriles was studied using the $F_{1}$ and $F_{2}$ generations of the triple cross, male sterile $B 15 B \times F_{1}$ progeny of MS-3A $\times$ QPL-1, where MS-3A possesses the gene conditioning translucent anthers.

\section{(i) Inheritance of $B 15 B$ male sterility}

All $F_{1}$ progeny of crosses of the three cultivars to male sterile $B 15 B$ plants were fertile. $F_{2}$ progenies of seven, six and two $F_{1}$ plants of crosses to 3D8103, QPL-1 and Royes, respectively, were studied. The results fitted a 3 fertile: 1 sterile ratio in all cases (all $P>0.01$, most $P>0.05$ ), as did the pooled results within and across the crosses (table 1). The test cross progenies were of limited size but each fitted a $1: 1$ ratio, although the pooled results did not do so (table 1 ). These results suggest that B15B male sterility is conditioned by a single recessive gene.

Of $25 \mathrm{~F}_{6}$ progenies which segregated for male sterility, all but two statistically fitted a 3 fertile: 1 sterile ratio. The test of heterogeneity indicated that these progenies could be pooled and the total over all the segregating progenies agreed with the expected ratio of $3: 1(P>0 \cdot 05)$.

The $F_{2}$ population of the male sterile $B 15 B$ (yellow flowered) $\times$ cv Royes (red flowered) cross included plants with red, yellow and streaked flowers. Most of the male sterile plants had streaked flowers and no male sterile,

* Present Address: Plant Breeder, International Crops Research Institute for the SemiArid Tropics, Patancheru P.O., Andhra Pradesh - 502324 India. 
TABLE 1

Segregation for male sterility in $F_{2}$ and test cross generations in three crosses, and in triple cross $F_{2}$ progenies

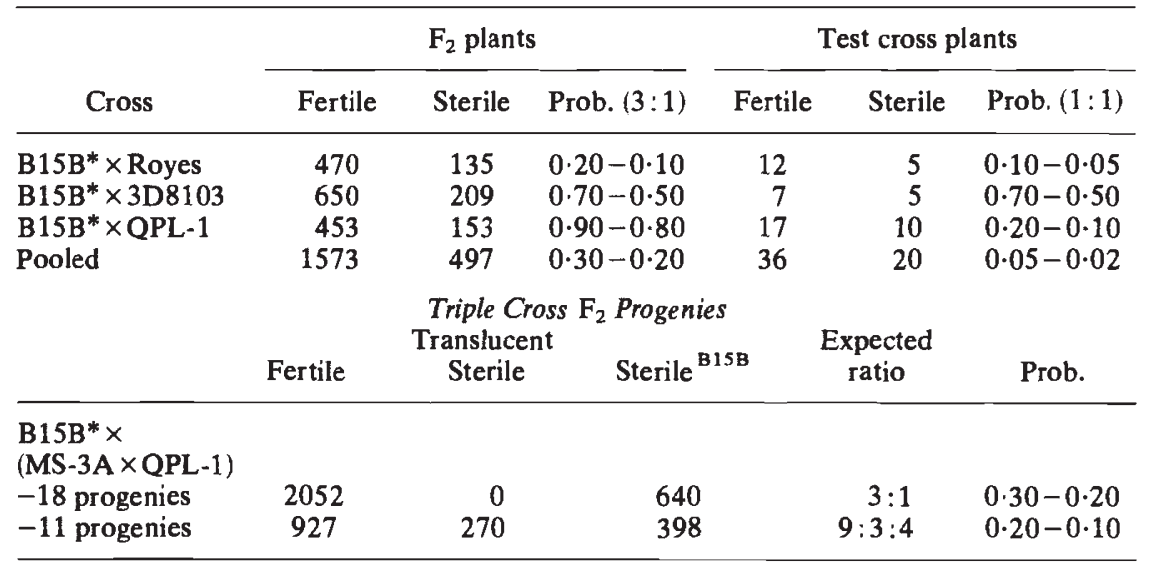

* Male sterile.

red flowered plants were found. Only a very low frequency of male fertile, yellow flowered plants occurred. This suggests that the allele conditioning male sterility in B15B is closely linked with one or more of those conditioning yellow flower colour. Detailed linkage studies are in prgress.

\section{(ii) Allelic relationship of $B 15 B$ and translucent characters}

All 23 triple-cross $F_{1}$ plants evaluated were male fertile, indicating that the translucent anther and B15B male sterile characters are conditioned by different genes. Of 29 triple-cross $F_{2}$ progenies, 18 segregated only for B15B sterility and 11 segregated for both the B15B and translucent anther types. This fitted a $1: 1$ ratio $(P>0.05)$. With one marginal exception, in all the $F_{2}$ 's segregating only for B15B type male sterility a good fit to a 3 fertile : 1 male sterile ratio was observed. The pooled values (table 1) also fitted to a $3: 1$ ratio. Eight of the 11 populations fitted well to a 9 fertile: 3 translucent anther: $4 \mathrm{~B} 15 \mathrm{~B}$ male sterile ratio $(P>0.05)$. Of the other three populations, one was significant $(P<0 \cdot 01)$ while two had very small number of plants ( 8 and 22 , respectively). The pooled values over all $11 F_{2}$ populations fitted a $9: 3: 4$ ratio (table 1 ).

These results indicate that the translucent anther and B15B male sterile characters are conditioned by different and independent gene systems. The gene symbol, $\mathrm{ms}_{2}$, is proposed for $\mathrm{B} 15 \mathrm{~B}$ male sterility. Although the $\mathrm{ms}_{1}$ and $\mathrm{ms}_{2}$ genes segregate independently, the $\mathrm{ms}_{2}$ gene acts to over-ride the expression of $\mathrm{ms}_{1}$ since the $\mathrm{ms}_{1} \mathrm{~ms}_{1} \mathrm{~ms}_{2} \mathrm{~ms}_{2}$ genotype exhibts the B15B male sterile phenotype. Presumably this is due to the earlier degeneration of pollen mother cells in the B15B type (Dundas et al., 1981).

Acknowledgements. This project was supported financially by International Crops Research Institute for the Semi-Arid Tropics (ICRISAT) and a Commonwealth of Australia Special Research Grant. Technical Assistance of Mr. C. Brauns was invaluable. 


\section{REFERENCES}

REDDY, B. V. S., REDDY, L. J. AND MURTHI, A. N. 1977. Reproductive variants in Cajanus cajan (L.) Millsp. Trop. Grain Legume Bull., 7, 11.

REDDY, B. V. S., GREEN, J. M. AND BISEN, S. S. 1978. Genetic male sterility in pigeonpea, Crop Sci., 18, 362-364.

DUNDAS, I. S., SAXENA. K. B. AND BYTH, D. E. 1981. Microsporogenesis and anther wall development in male-sterile lines of pigeonpea (Cajanus cajan (L.) Millsp.). Euphytica, $30,431-435$.

WALlis, E. S., SAXENA, K. B. AND BYTH, D. E. 1981. A new source of male sterility in pigeonpea. In Proc. Intl. Workshop on pigeonpeas, Volume 2, 15-19 December, 1980. Patancheru, A. P. India, pp. 105-108. 